\title{
The Effect of the Extracorporeal Shock Wave Therapy on Scaphoid Fracture Nonunions
}

\author{
AMR E. AHMED, M.Sc.*; OMAIMA KATTABEI, Ph.D.*; AHMED F. GENEDY, M.D.** and \\ ABER RAMADAN, Ph.D.* \\ The Department of Basic Sciences, Faculty of Physical Therapy, Cairo University* and The Department of Physical Medicine, \\ Military Medical Academy**, Cairo
}

\begin{abstract}
Background: The scaphoid is the most frequently fractured carpal bone, typically as a result of a fall onto an outstretched hand. Nonunion that caused by poor blood supply is an important complication of scaphoid fracture. The purpose of this study was to investigate the effect of the extracorporeal shock wave therapy on the healing of scaphoid fracture nonunion.
\end{abstract}

Subjects: Thirty patients from both genders were diagnosed with scaphoid fracture for more than sex weeks without healing for more than six monthes, aged 20 to 50 years and were divided into two equal groups; fifteen patients each.

Method: Subjects were randomly divided into 2 groups; group A (control group) received conservative treatment (immobilization with cast and follow-up). Group B (experimental group) received three ESWT sessions followed by immobilization by cast. X-ray radiographs were obtained before and after treatment.

Results: There were significant statistical differences between the 2 groups, where the treatment group showed greater improvement in the healing response.

Conclusion: ESWT is an effective method in treatment of scaphoid fracture nonunion.

Key Words: Scaphoid bone - Nonunion fracture - Shock wave therapy.

\section{Introduction}

THE word Scaphoid is derived from Greek language. "Skaphos" in Greek means boat. Scaphoid is a boat shaped bone. Scaphoid bone is also known as navicular. The articular cartilage covers $80 \%$ ofthe bone surface. It is placed at $45^{\circ}$ to the longitudinal axis of the wrist. It articulates with capitate, trapezium, and trapezoid distally, distal radius proximally and lunate medially. The scaphoid is a biomechanically important, boat-shaped carpal bone "skaphos", that articulates with the distal

Correspondence to: Dr. Amr E. Ahmed, The Department of Basic Sciences, Faculty of Physical Therapy, Cairo University radius, trapezium, and capitate. During radial deviation and dorsiflexion of the wrist, the scaphoid encroaches on the radius, limiting this motion. If this motion is forceful (e.g., a fall on an outstretched arm), enough stress on the scaphoid occurs to fracture it [1]

The scaphoid is the most frequently fractured carpal bone, typically as a result of a fall onto an outstretched hand. The fracture usually crosses the long axis of the bone. Fractures of its proximal part or its 'waist' may fail to unite because the proximal fragment has lost its blood supply: Avascular necrosis of the proximal fragment is then inevitable. The blood supply of the scaphoid comes from the radial artery, feeding the bone on the dorsal surface near the tubercle and scaphoid waist. Because the proximal portion has no direct blood supply, nonunion caused by poor blood supply is an important complication of scaphoid fracture [2]

Scaphoid fractures account for almost $75 \%$ of all carpal fractures. The usual mechanism is a fall on the hand with wrist extended. The critical movement is probably a combination of dorsiflexion and radial deviation, with the force passing between the two rows of carpal bones; the scaphoid, lying partly in each row, fractures across its waist. The injury is rare in children and in the elderly. The blood supply of the scaphoid diminishes proximally. This accounts for the fact that $1 \%$ of distal-third fractures, $20 \%$ of middle-third fractures and $40 \%$ of proximal fractures result in non-union or avascular necrosis of the proximal fragment [3]

Shock waves is defined as a sequence of single sonic pulses characterized by high peak pressure $(100 \mathrm{MPa})$, fast pressure rise $(<10 \mathrm{~ns})$ and short lifecycle $(10 \mu \mathrm{s})$, are conveyed by an appropriate 
generator to a specific target area with the energy density in the range of $0,003-0,890 \mathrm{~mJ} / \mathrm{mm}^{2}$ [4].

A shock wave is essentially a pressure disturbance that propagates rapidly through a medium. It can be defined thus: A large amplitude compression wave, as that produced by an explosion or by supersonic motion of a body in a medium [5] .

Shock waves were initially employed as a non invasive treatment for kidney stones, and it has become a first line intervention for such conditions. In the process of the animal model experimentation associated with this work, it was identified that shock waves could have an effect on bone. This lead to a series of experimental investigations looking at the effect of shock waves on bone, cartilage and associated tissues (tendon, ligament, fascia) resulting in what is now becoming an intervention of increasing popularity, most especially for the recalcitrant lesions of these tissues, though the clinical uses are expanding and now include wound management, treatment of fractures and numerous additional applications [6] .

The shock waves are sound waves that are generated by a source that create vibrations which are then transported through tissues via fluid and solid. Shock wave therapy involves delivering intermittent sound waves that can travel only through fluids, gases and solids. They penetrate into the area to be treated via an interface, for instance, a gel applied to the skin. Low energy waves $\left(<0,1 \mathrm{~mJ} / \mathrm{mm}^{2}\right)$ relieve pain, whereas high energy waves $\left(0,2\right.$ to $\left.0,4 \mathrm{~mJ} / \mathrm{mm}^{2}\right)$ increase the regional blood flow, produce capillary lesions and promote growth of new capillaries [7].

The purpose of the study was to determine:

The effect of the ESWT on the healing of Scaphoid fracture nonunion.

\section{Subjects and Methods}

This study was conducted in Kobri El-Koba Military Hospital from March 2017-May 2017 to investigate the effect of ESWT on Scaphoid fracture nonunions.

Subjects: 30 patients diagnosed with scaphoid fracture were chosen from Naser Polyclinic-General Authoority of Health Insurance according to the following criteria:

Inclusion criteria:

- Thirty patients who had scaphoid fracture for more than 6 months.

- Their age was ranged from 20 to 50 years.
- All patients had scaphoid fracture for more than 6 months.

Exclusion criteria:

- Patients who have open or neoplastic fracture.

- Patients who have local infection.

- A bone gap more than $0.5 \mathrm{~cm}$.

- Patients with internal fixation.

- Pregnant women.

- Patients with pacemakers.

- Patients receiving anticoagulants or immunosuppressive drugs.

Patients were randomly divided (simple randomization) into two equal groups in number:

- Study group: This group was be composed of 15 patients who received the extracorporeal shock wave therapy followed by immobilization by cast.

- Control group: This group was be composed of 15 patients who received the regular medical conservative treatment.

\section{Instrumentations:}

1- Treatment instrument: Extracorporeal Shock Wave Therapy.

\section{Description:}

Apparatus name: Gymna Shock master 5000.

Country: Belgium.

Its uses: ESWT devices have been used for the treatment of plantar fasciitis, achilles tendinopathy, pseudarthrosis, fracture nonunion, femoral head necrosis, tibial stress syndrome, greater trochanter pain syndrome, delayed bone-tendon healing, subacromial pain, calcific tendinitis of the shoulder, rotator cuff tendinopathy, patellar tendinopathy, osteoporosis and lateral epicondylitis.

\section{2- Assessment instrument:}

The following tool was used to assess the healing response:

1- X-ray radiography.

\section{Procedures of the study:}

A verbal explanation about the importance of the research and main points of achievement eas explained to every patient. The procedures of the study were divided into two main categories:

\section{A- Therapeutic procedures:}

All patients in the 2 groups received the medical conservative treatment (immobilization and followup). 
Procedures of the extracorporeal shock wave therapy (study group):

The pressure pulses was focused on the fracture gab and on the adjacent cortical structures with Xray localization, 1500 shots was used and the energy will be $0,2 \mathrm{~mJ} / \mathrm{mm}^{2}$.

Each treatment cycle included 3 sessions at intervals of 72 hours between sessions; a maximum 3 cycles of treatment was given at 1 month interval.

After ESWT treatment, immobilization was required to achieve the full stabilization of the fracture.

\section{$B$ - Measurement procedures:}

$\mathrm{X}$-ray radiography: Antro-posterior and oblique views of the scaphoid bone were taken pre and post-treatment.

\section{C- Data analysis:}

- In this study, the mean, the standard deviation and the standard error were calculated for all patients ( 2 groups of the study) after the detected time of the study and Chi square test was used to compare the healing response between both groups at pre and post-treatment.

- The level of significance was set at the 0.05 level.

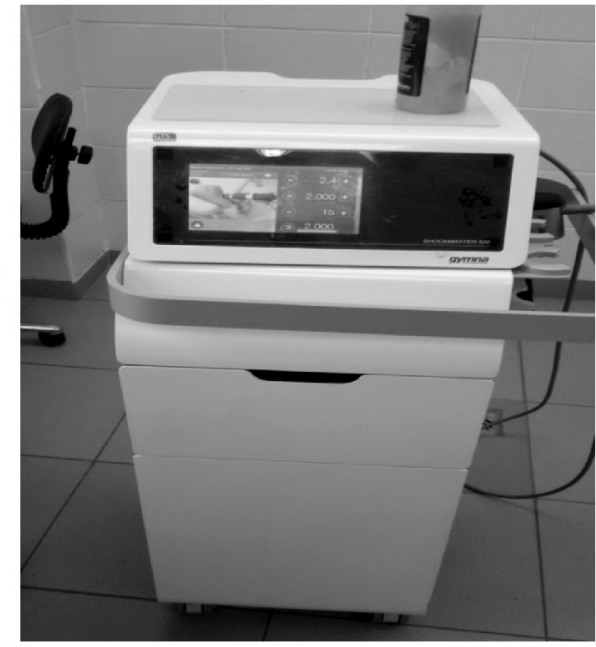

Fig. (1): ESWT apparatus.

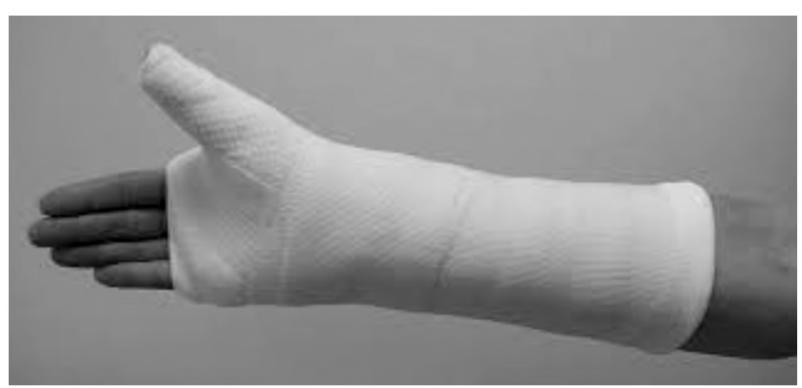

Fig. (2): Immobilization with cast.

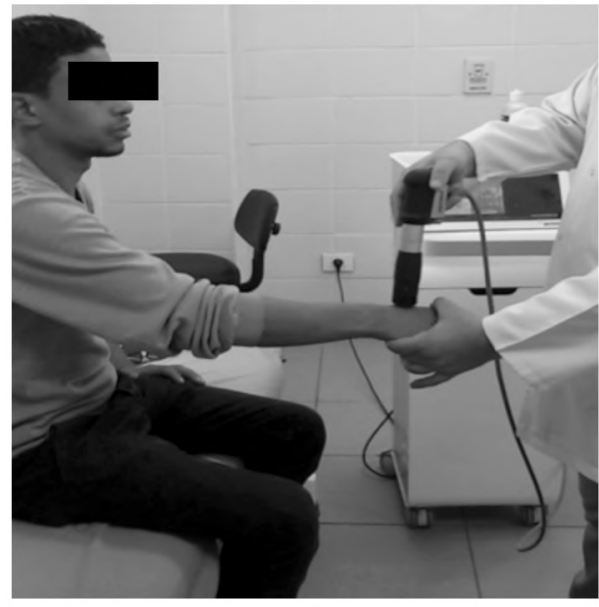

Fig. (3): ESWT application.

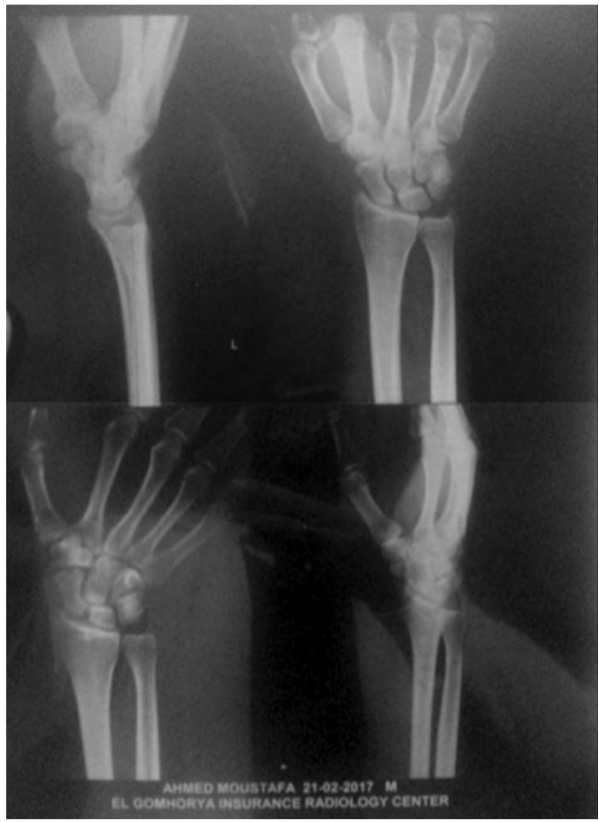

Fig. (4): X-ray of scaphoid fracture.

\section{Results}

Statistical analysis was conducted using SPSS for windows, Version 20 (SPSS, Inc., Chicago, IL). The current test involved two independent variables. The first one was the between subject factor which had two levels (group A received conservative treatment and group B received ESWT followed by immobilization). The second one was the (measuring periods); within subject factor which had two levels (pre-treatment, post-treatment). In addition, this test involved one tested dependent variable (healing response) which is nominal variable. As there was no variation at pre treatment that all response in both groups was unhealed, so the McNemar test cannot be used and the frequency distribution and its percent only used to describe the difference within groups. While between groups Chi square test was used to com- 
pare the healing response between both groups at pre and post-treatment. With the initial alpha level set at 0.05 .

\section{General characteristics:}

The current study was conducted on thirty patients suffered from scaphoid fracture nonunion. They were assigned randomly into two equal studies groups.

\section{Group A:}

Fifteen patients with scaphoid fracture nonunion were included in this group. The data in (Table 1) and Figs. (5-7) represented their mean age (39 \pm $7.37)$ years, mean weight $(80.8 \pm 5.22)$ kilograms $(\mathrm{Kg})$, and mean height $(169.66 \pm 5.36)$ centimeters (cm) respectively.

\section{Group B:}

Fifteen patients with scaphoid fracture nonunion were included in this group. The data in (Table 1) and Figs. (5-7) represented their mean age (39.6 \pm 8.3 ) years, mean weight $(80.4 \pm 6.5)$ kilograms $(\mathrm{Kg})$, mean height $(171.33 \pm 4.67)$ centimeters $(\mathrm{cm})$ respectively. There was no significant difference between both groups in their ages, weights, and heights where their $t$ and $p$-values were $(t=0.209$, $p=0.836),(t=0.186, p=0.854)$, and $(t=0.907$, $p=0.372$ ) respectively.

\section{Sex distribution:}

The sex distribution of control group revealed that there were 6 females with reported percentage of $40 \%$ and 9 males with reported percentage of $60 \%$. The sex distribution of study group revealed that there were 4 females with reported percentage of $26.6 \%$ and 11 males with reported percentage of $73.4 \%$ as shown in (Table 2). Chi square revealed there was no significant differences between both groups in sex distribution $(p>0.05)$.

\section{Healing response:}

\section{1- Within groups:}

As presented in (Table 3) and illustrated in Fig. (8), within groups comparison the frequency distribution of the healing response for group A in the "pre-treatment" was 15 subjects with unhealed response that reported percentage of $100 \%$. As well as in the "post-treatment" was 15 subjects with unhealed response that reported percentage of $100 \%$. Meanwhile, the frequency distribution of the healing response for study group in the "pretreatment" was 15 subjects with unhealed response that reported percentage of $100 \%$. While in the "post-treatment" were 12 subjects with healed response that reported percentage of $80 \%$ and 3 subjects with unhealed response that reported percentage of $20 \%$.

\section{2- Between groups:}

As presented in (Table 3), the effect of the tested group (first independent variable) on the healing response by using Chi square revealed that the frequency distribution of the healing response of the "pre treatment" between both groups revealed that there was no significant difference $(\chi=0.000$ and $p=1.00$ ). While, Chi square revealed that the frequency distribution of the healing response of the "post-treatment" between both groups showed that there was significant difference $(\chi=24$ and $p=0.0001 *)$ and this significant increase in healing response in favor of studty group.

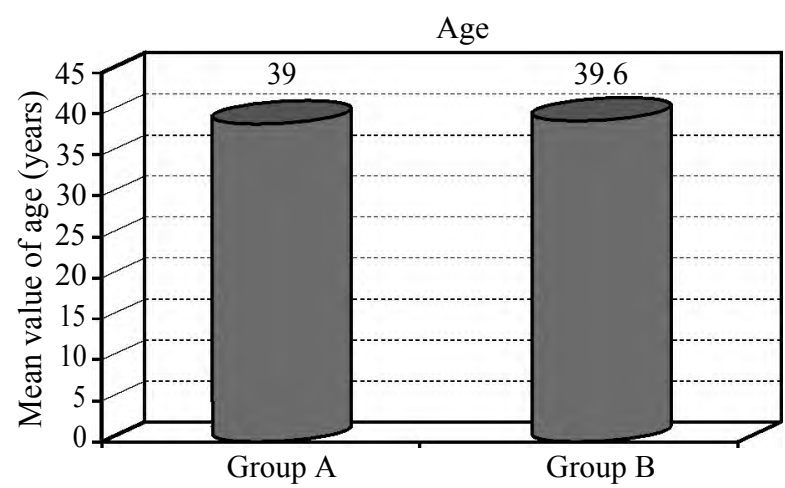

Fig. (5): Mean value of the age for both groups.

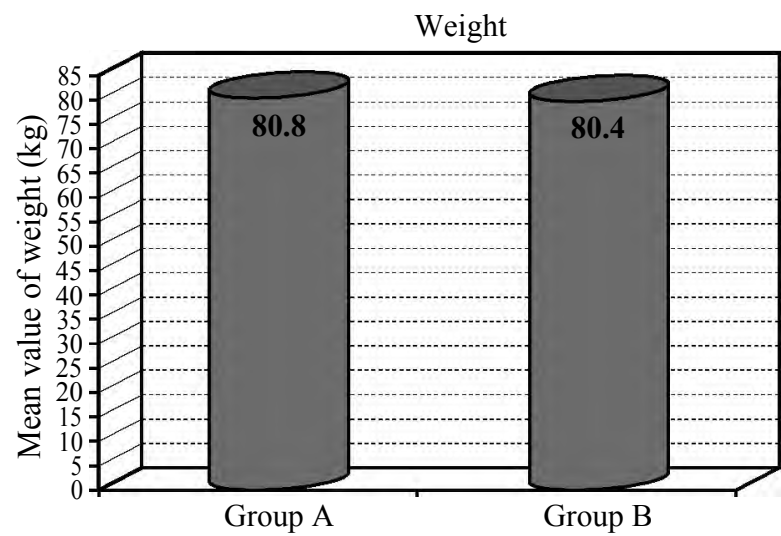

Fig. (6): Mean value of the weight for both groups.

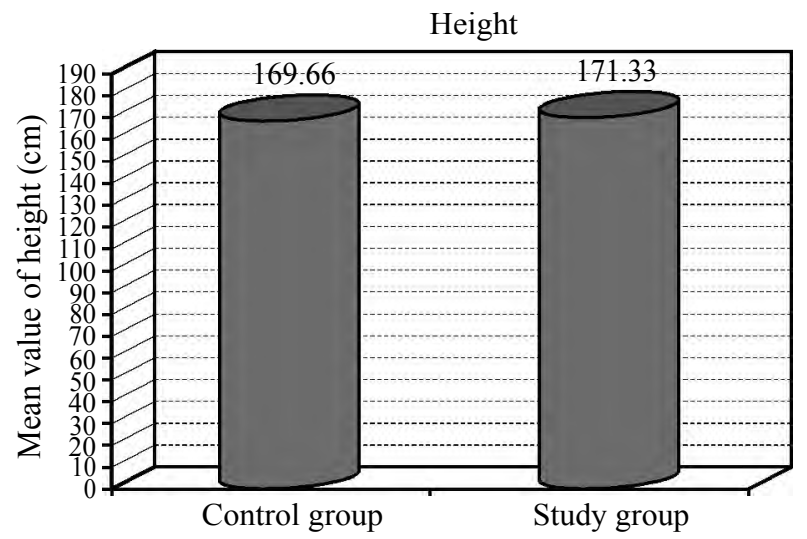

Fig. (7): Mean value of the height for both groups. 


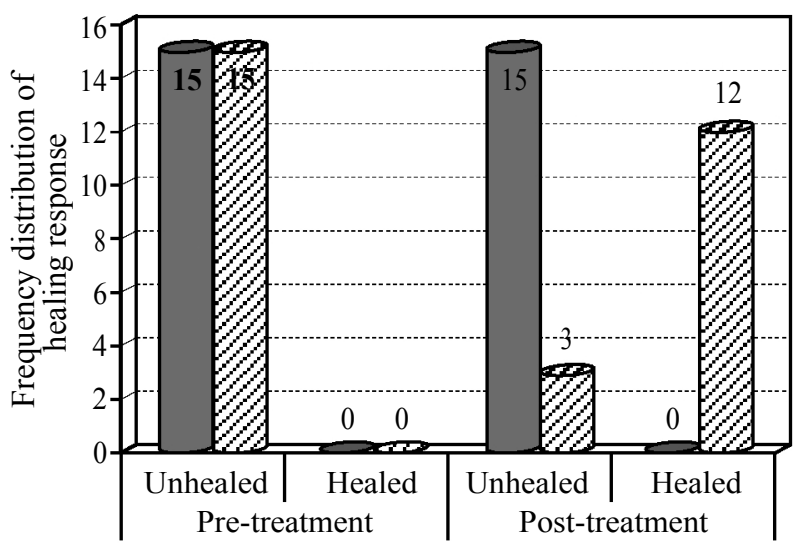

Group A $Q 2$ Group B

Fig. (8): Frequency distribution of healing response in pre and post-treatment at both groups.

Table (1): Physical characteristics of patients in both groups.

\begin{tabular}{|c|c|c|c|c|c|}
\hline \multirow[b]{2}{*}{ Items } & \multirow{2}{*}{$\begin{array}{c}\text { Control } \\
\text { group } \\
\text { Mean } \pm \text { SD }\end{array}$} & \multirow{2}{*}{$\begin{array}{c}\text { Study } \\
\text { group } \\
\text { Mean } \pm \text { SD }\end{array}$} & \multicolumn{2}{|c|}{ Comparison } & \multirow[b]{2}{*}{ S } \\
\hline & & & $\begin{array}{c}t- \\
\text { value }\end{array}$ & $\begin{array}{c}p- \\
\text { value }\end{array}$ & \\
\hline Age (yrs) & $39 \pm 7.37$ & $39.6 \pm 8.3$ & -0.209 & 0.836 & $\overline{\mathrm{NS}}$ \\
\hline Weight $(\mathrm{Kg})$ & $80.8 \pm 5.22$ & $80.4 \pm 6.5$ & 0.186 & 0.854 & NS \\
\hline Height $(\mathrm{cm})$ & $169.66 \pm 5.36$ & $171.33 \pm 4.67$ & -0.907 & 0.372 & NS \\
\hline
\end{tabular}

Table (2): Distribution of sex in both groups.

\begin{tabular}{|c|c|c|c|c|c|}
\hline & \multirow{2}{*}{$\frac{\text { Group A }}{\text { Females Males }}$} & \multicolumn{2}{|c|}{ Group B } & \multicolumn{2}{|c|}{ Chi-square } \\
\hline & & Females & Males & $x^{2}$ & $p$-value \\
\hline $\begin{array}{l}\text { No. } \\
\text { Total }\end{array}$ & $\begin{array}{l}6(40 \%) 9(60 \%) \\
15(100 \%)\end{array}$ & $\begin{array}{l}4(26.6 \%) \\
15(100 \%)\end{array}$ & $11(73.4 \%)$ & 0.600 & 0.439 \\
\hline
\end{tabular}

Table (3): Frequency distribution and Chi square tests of the healing response for each group at pre and posttreatment.

\begin{tabular}{lcclcc}
\hline \multirow{2}{*}{$\begin{array}{l}\text { Healing } \\
\text { response }\end{array}$} & \multicolumn{2}{c}{ Group A } & & \multicolumn{2}{c}{ Group B } \\
\cline { 2 - 3 } \cline { 5 - 6 } \cline { 5 - 6 } & Unhealed & Healed & & Unhealed & Healed \\
\hline Pre-treatment & $15(100 \%)$ & $0(0 \%)$ & & $15(100 \%)$ & $0(0 \%)$ \\
Post-treatment & $15(100 \%)$ & $0(0 \%)$ & $3(20 \%)$ & $12(80 \%)$ \\
\hline Group A vs. group B & Pre-treatment & Post-treatment \\
\hline$\chi^{2}$-value & 0.000 & & 20 \\
$p$-value & 1.00 & & $0.0001 *$ \\
\hline
\end{tabular}

*: Significant at alpha level $<0.05$.

\section{Discussion}

This study was conducted to study the effect of ESWT on scaphoid fracture non union.

Thirty patients with scaphoid fracture non union (20 males and 10 females) aged from 20 to 60 years, randomly assigned into two groups, subjects in the control group received conservative treatment (immobilization with cast and follow-up) while subjects in the study group received 3 sessions of ESWT with interval of 72 hours followed by immobilization for a month to achieve full stabilization of the fracture.

The results in the control group showed that the healing response was $0 \%$ (100\% unhealed).

The results in the study group showed that the healing response was $80 \%$ healed while $20 \%$ unhealed.

The comparison between the control group and the study group showed that the healing response in the study group was $80 \%$ while in the control group was $0 \%$.

This means that there was a statistically significant difference between both groups.

Finally, according to the previous discussion and the results of the present study, it could be suggested that ESWT can be an effective method in the treatment of scaphoid fracture nonunion.

\section{Conclusions:}

Within the limitations of the study it can be concluded that ESWT is an effective method in treatment of scaphoid fracture nonunion.

\section{References}

1- PHILlIPS T.G., REIBACH A.M. and SLOMIANY W.P.: Diagnosis and management of scaphoid fractures. Am. Fam. Physician, 70 (5): 879-84. Retrieved from http:// www. aafp. org/ afp /2004/ 0901/p879.html, 2004.

2- SCHUBERT H.E.: Scaphoid fracture. Review of diagnostic tests and treatment. Can. Fam. Physician., 46: 1825-32. Retrieved from http://www.pubmedcentral.nih.gov/ articlerender.fcgi?artid=2145017\&tool=pmcentrez \&rendertype $=$ abstractm, 2000 .

3- PHILLIPS T.G., REIBACH A.M. and SLOMIANY W.P.: Diagnosis and management of scaphoid fractures. Am. Fam. Physician., 70 (5): 879-84. Retrieved from http://. www.aafp.org/afp/2004/0901/p879.html. 2004.

4- CIAMPA A.R., PRATI A.C. and AMELIO E.: Nitric oxide mediates anti inflammatory action of shock waves. F.E.B.S. Letters, 579 (19): 6839-45, 2005.

5- McCLURE S. and WEINBERGER T.: Extracorporeal shock wave therapy; clinical applications and regulations, 358-67, 2003.

6- WANG C.J., HUANG H.Y. and PAI C.H.: Shock waveenhanced neovascularization at the tendon-bone junction: An experiment in dogs. J. Foot Ankle. Surg., 41: 16-22, 2002.

7- CACCHIO A., PAOLONI M. and BARILE A.: Effectiveness of radial shock wave therapy for calcific tendinitis of the shoulder: Single blind randomized clinical study. Physical Therapy, 86 (5): 672-80, 2006. 
8- MARTINI L., GIAVARESI G., FINI M., TORRICELLI P., De PRETTO M., SCHADEN W. and GIARDINO R.: Effect of extracorporeal shock wave therapy on osteoblastlike cells. Clin. Orthop. Relat. Res., 413: 269-80, 2003.

9- McCLURE S. and WEINBERGER T.: Extracorporeal shock wave therapy; clinical applications and regulations; 358-67, 2003.

10- WANG C.J., WANG F.S. and YANG K.D.: Biological effects of extracorporeal shockwave in bone healing: A study in rabbits. Arch. Orthop. Trauma. Surg., 128: 87984, 2008.

11- MAIER M., MILZ S. and TISCHER T.: Influence of extracorporeal shock-wave application on normal bone in an animal model in vivo. Scintigraphy, MRI and histopathology. J. Bone Joint Surg. Br., 84 (4): 592-9, 2002.

12- SCHADEN W., FISCHER A. and SAILLER A.: Extracorporeal shock wave therapy of nonunion or delayed osseous union. Clin. Orthop. Relat. Res., 387: 90-4, 2001.

\section{تآثير العلاج بالموجات التصادمية على كسر الزورقيه الغير ملتئم}

المقدمة: كسر عظمة الزوقيه هو الآكثر شيوعا بين عظام الرسن كما يعتبر الكسر الغير ملتئم من المضاعفات الثائعة لكسر عظمة الزوقيه نتيجة لضعف الدوة الدموية.

الهدف: يهدف هذا البحث إلى دراسة لإختبار تآثير العلاج بالموجات التصادمية على كسر عظمة النوقيه الغير ملتئم.

الآشختاص: وقد آجرى هذا البحث على .ب مريض من الجنسين حيث تم تشخيصهم بكسر بعظمة الزوقيه الغير ملتئم لمدة تزيد عن ستة

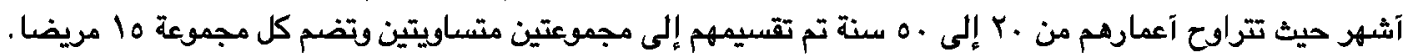

الطريقةة: تم تقسيم المرضى عشوائيا إلى مجموعتين متساويتين وهما المجموعة التجريبية وتضم 10 مريضا والمجموعة الحاكمة وتضم

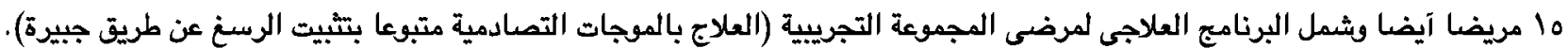

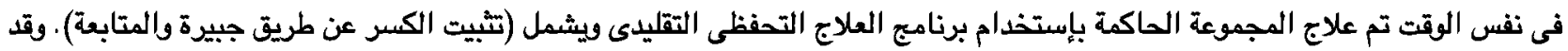
تم تقييم الحالات عن طريق آثعة آكس وقد آجريت القياسات لهاتين المجموعتين قبل وبعد الفترة العلاجية.

النتائج:وقد تم تحليل النتائج إحصائيا وقد وجد إختلافات ذات دلالة إحصائية بين المجموعتين بينما وجدت إختلافات كبيرة ذات دلالة

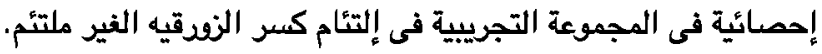

الخاتمهة: تعتبر الموجات التصادمية طريقة علاجية فعالة لعلاج كسر الزوقيه الغير ملتئم. 